\title{
Estimating genetic and phenotypic parameters of cellular immune-associated traits in dairy cows
}

\author{
Scott J. Denholm, ${ }^{* 1}$ Tom N. McNeilly, $\dagger$ Georgios Banos, ${ }^{*}$ Mike P. Coffey, ${ }^{*}$ George C. Russell, $\dagger$ \\ Ainsley Bagnall, ${ }^{*}$ Mairi C. Mitchell, $\dagger$ and Eileen Wall* \\ *Scotland's Rural College (SRUC), Kings Buildings, West Mains Road, Edinburgh, EH9 3JG, United Kingdom \\ †Moredun Research Institute, Pentlands Science Park, Midlothian EH26 OPZ, Scotland, United Kingdom
}

\section{ABSTRACT}

Data collected from an experimental HolsteinFriesian research herd were used to determine genetic and phenotypic parameters of innate and adaptive cellular immune-associated traits. Relationships between immune-associated traits and production, health, and fertility traits were also investigated. Repeated blood leukocyte records were analyzed in 546 cows for 9 cellular immune-associated traits, including percent $\mathrm{T}$ cell subsets, B cells, NK cells, and granulocytes. Variance components were estimated by univariate analysis. Heritability estimates were obtained for all 9 traits, the highest of which were observed in the $\mathrm{T}$ cell subsets percent $\mathrm{CD} 4^{+}$, percent $\mathrm{CD} 8^{+}, \mathrm{CD} 4^{+}: \mathrm{CD} 8^{+}$ratio, and percent $\mathrm{NKp} 46^{+}$cells $(0.46,0.41,0.43$ and 0.42 , respectively), with between-individual variation accounting for 59 to $81 \%$ of total phenotypic variance. Associations between immune-associated traits and production, health, and fertility traits were investigated with bivariate analyses. Strong genetic correlations were observed between percent $\mathrm{NKp} 46^{+}$and stillbirth rate (0.61), and lameness episodes and percent $\mathrm{CD} 8^{+}$ $(-0.51)$. Regarding production traits, the strongest relationships were between $\mathrm{CD} 4^{+}: \mathrm{CD} 8^{+}$ratio and weight phenotypes $(-0.52$ for live weight; -0.51 for empty body weight). Associations between feed conversion traits and immune-associated traits were also observed. Our results provide evidence that cellular immune-associated traits are heritable and repeatable, and the noticeable variation between animals would permit selection for altered trait values, particularly in the case of the $\mathrm{T}$ cell subsets. The associations we observed between immune-associated, health, fertility, and production traits suggest that genetic selection for cellular immune-associated traits could provide a useful tool in improving animal health, fitness, and fertility.

Received June 29, 2016.

Accepted December 8, 2016.

${ }^{1}$ Corresponding author: scott.denholm@sruc.ac.uk
Key words: dairy cow, immune-associated trait, heritability, variance

\section{INTRODUCTION}

Dairy cow health represents a major constraint on production and is a significant cause of poor welfare. This is particularly true in the case of the modern highyielding dairy cow, where periods such as early lactation carry a heightened risk of disease and susceptibility to mastitis and other mammary infections is increased (Collard et al., 2000; McDougall et al., 2007). Genetic selection for increased milk yield has been highly successful; however, it has also resulted in unforeseen negative effects on health, longevity, and production (Pryce et al., 2004; Oltenacu and Broom, 2010; Koeck et al., 2013; Pritchard et al., 2013). The ability to predict the occurrence of disease in dairy cows is crucial in maintaining a high level of production within a herd as well as ensuring any financial loss is kept to a minimum (Huijps et al., 2008). Two examples of approaches to improve dairy cow health are to identify phenotypic markers (i.e., biomarkers) that can be used to predict the occurrence of health events and allow early intervention, or to identify heritable traits associated with improved health function for use in future genetic-selection programs aimed at reducing disease incidences and health conditions. Recently, interest has been growing in identifying and measuring immune-associated (IA) phenotypes in livestock, which could then be associated with disease or health conditions. Such IA phenotypes could be used to estimate an individual's susceptibility to disease or act as biomarkers of concurrent disease (Park et al., 2004; Clapperton et al., 2005, 2008, 2009; Flori et al., 2011a,b; Thompson-Crispi et al., 2012a,b; van Knegsel et al., 2012; Banos et al., 2013). Previous research has looked at either steady-state measurements, such as circulating leukocyte populations, acute phase proteins, and serum cytokine levels (Park et al., 2004; Glass et al., 2005; Clapperton et al., 2005, 2008; Flori et al., 2011a,b; Banos et al., 2013), or in vitro measurements of immune responsiveness focusing 
on innate and adaptive arms of the immune response (Thompson-Crispi et al., 2012a,b, 2014b; Heriazon et al., 2013; Mallard et al., 2015). Moreover, it has been suggested that including measurable immune response phenotypes in selection indices may be a viable option to decrease disease and improve animal health (AbdelAzim et al., 2005; Thompson-Crispi et al., 2012a; Mallard et al., 2015)

Previously, using a cohort of 248 lactating HolsteinFriesian dairy cows sampled repeatedly over a 10-mo period, we identified several cellular IA traits within the circulating leukocyte population that were significantly associated with important health, fertility, and lactation traits, including mastitis, lameness, and infertility. These included a negative association between the $\mathrm{CD} 4^{+}: \mathrm{CD}^{+} \mathrm{T}$ lymphocyte ratio and subclinical mastitis, a negative association between percent $\mathrm{CD} 8^{+}$ $\mathrm{T}$ lymphocytes within the total circulating leukocyte population and fertility, and a positive association between percent $\mathrm{NKp} 46^{+}$leukocytes and lameness. Furthermore, these cellular measures were highly repeatable and displayed significant between-animal variation, suggesting they may be altered by genetic selection (Banos et al., 2013).

The aim of the present study was to add to the previous findings by using a larger data set, and corresponding pedigree information, to estimate genetic and phenotypic variance components for various subsets of blood leukocytes. Further, we investigated the genetic and phenotypic associations between these cellular IA traits and health, fertility, production, and functional traits (e.g., SCC, feed intake, live weight, BCS) in dairy cows.

\section{MATERIALS AND METHODS}

\section{Animals}

All animals in the study population were HolsteinFriesians from the Langhill lines of dairy cattle housed at the Scotland's Rural College Dairy Cattle Research Centre at Crichton Royal Farm, Dumfries, Scotland. Cows were born between January 2003 and September 2012 and were between their 1st and 5th lactation (inclusive). Cows in the Langhill herd are routinely and extensively monitored for productivity, health, welfare, and reproduction, generating a wealth of phenotypic data for use in statistical analyses. Full pedigree spanning 7 generations was available.

Langhill cows are involved in an on-going selection experiment in a 2 by 2 approach (genetic line $\times$ feeding systems) that has been running for over $30 \mathrm{yr}$ (Veerkamp et al., 1994). Cows are divided equally between 2 genetic groups: a control and a select. Those in the control group were daughters of sires selected with the UK-average genetic merit for milk fat and protein. In contrast, cows in the select group were from sires selected with the highest genetic merit for milk fat and protein (Pryce et al., 1999; Bell et al., 2011). Within each genetic group, cows were also divided among 2 distinct feed groups that aimed to be divergent in terms of energy content. From 2002 to 2009 animals were split between an indoor nongrazing, low-forage system with a target $\mathrm{ME}$ of $12.3 \mathrm{MJ} / \mathrm{kg}$ of $\mathrm{DM}$, with the other half of the herd receiving a high-forage diet with summer grazing with a target ME of $11.5 \mathrm{MJ} / \mathrm{kg}$ of DM. From September 2009 cows moved to different diets, either a home-grown forage diet (home-grown) or a boughtin by-product feed (by-product). Over summer, the animals on the home-grown forage diet were at grass during the day and overnight they were offered a feed of appropriate home-grown ingredients to balance the high protein and relatively low NDF of the grass. The by-product diet was based on ingredients available following a primary production process and not normally used for human food (March et al., 2016).

\section{Data}

Detailed animal performance data were collected on the cows routinely while they were on the genetic line $x$ feeding systems. The present study included 546 cows with IA trait information. Of these, 256 were previously included in Banos et al., (2013). An additional 246 cohorts without IA trait information were also available and included in the bivariate analyses, resulting in a total of 792 cows with yield, reproductive, and health measures. The data are summarized in Table 1 and described in further detail below.

IA Traits. Blood samples were collected on 12 separate occasions from 358 animals (2,266 total samples). One sample per cow was collected every other month

Table 1. Description of phenotype data set used in all model analyses

\begin{tabular}{lr}
\hline Description & Total \\
\hline Weekly production and functional phenotypic records & 92,153 \\
Weekly cellular immune-associated, health, and fertility & 3,581 \\
records & \\
Animals in data set & 792 \\
Animals with immune data & 546 \\
Animals with phenotypic data only & 246 \\
Lactations & $3^{1}$ \\
Years (2005-2015) & 10 \\
Animals in pedigree & 2,793 \\
Sires & 539 \\
Dams & 1,813 \\
Generations & 7 \\
\hline
\end{tabular}

$\overline{{ }_{1}^{1}, 785 \text { total lactations. Note: lactations } \geq 3 \text { are grouped into the lacta- }}$ tion 3 class. 
(i.e., at 2-mo intervals) during the sampling period between April 2013 and March 2015 and included summer and winter samplings. Blood leukocyte subpopulations in each sample were analyzed by flow cytometry to derive 9 cellular IA traits: percent peripheral blood mononuclear cells (PBMC), percent eosinophils, percent lymphocytes, percent monocytes, percent neutrophils, percent $\mathrm{CD} 4^{+}$, percent $\mathrm{CD} 8^{+}, \mathrm{CD} 4^{+}: \mathrm{CD} 8^{+}$ratio, and percent $\mathrm{NKp} 46^{+}$.

The additional data from Banos et al., (2013) were collected every other month on 5 separate occasions between July 2010 and March 2011. Cellular IA trait information from the Banos et al. (2013) data was only available for animals on the high-concentrate diet (Banos et al., 2013). This additional data accounted for approximately $25 \%$ of the total IA trait data set.

Flow Cytometry. For flow cytometric analysis of circulating leukocyte populations, blood samples were collected into EDTA Vacutainers (BD, Franklin Lakes, NJ). Red blood cell lysis and antibody labeling was performed in 96-well round-bottomed plates as follows: $25 \mu \mathrm{L}$ of EDTA whole blood was added per well and subsequently incubated with $125 \mu \mathrm{L}$ of ammonium chloride lysis buffer $\left(0.15 M \mathrm{NH}_{4} \mathrm{Cl}, 10 \mathrm{~m} M \mathrm{NaHCO}_{3}, 1\right.$ $\mathrm{m} M$ disodium EDTA, pH 7.4). After red blood cell lysis was complete, leukocytes were pelleted by centrifugation at $850 \times g$ for $1 \mathrm{~min}$ at $4^{\circ} \mathrm{C}$ and washed twice with flow cytometry buffer $(5 \%$ fetal bovine serum and $0.02 \%$ sodium azide in PBS) before incubating at $4^{\circ} \mathrm{C}$ for $30 \mathrm{~min}$ in flow cytometry buffer containing $10 \%$ heat-inactivated normal mouse serum (Invitrogen, Carlsbad, CA). Cell measurements were focused on cell types which had been shown to correlate with health and productivity traits in our previous study (Banos et al., 2013). Cells were then incubated at $4^{\circ} \mathrm{C}$ for 30 min with the following monoclonal antibodies: antibovine CD4 conjugated to Alexa Fluor 647 (clone CC8, mouse IgG2a, AbD Serotec, Bio-Rad, Hercules, CA), anti-bovine CD8 conjugated to R-phycoerythrin (clone CC63, mouse IgG2a, AbD Serotec), and anti-bovine CD335 conjugated to Alexa Fluor 488 (clone AKS1, mouse IgG1, AbD Serotec). Unstained control cells and isotype stained cells (mouse IgG1 conjugated to Alexa Fluor 488, mouse IgG2a conjugated to R-phycoerythrin, mouse IgG2a conjugated to Alexa Fluor 647; all eBioscience, San Diego, CA) were included on each plate. After final washes in FACS buffer then PBS, cells were fixed in $1 \%$ paraformaldehyde in PBS for 10 min at room temperature and then resuspended in PBS before analysis on a MACSQuant flow cytometer (Miltenyi Biotech, Bergisch Gladbach, Germany). Data analyses were performed using FlowJo version 7.6.1 analysis software (TreeStar, San Carlos, CA). The results were expressed as a percentage of cells within the PBMC population that were positive for each surface marker. In addition, differential cell counts were performed by analysis of unstained cells and identifying leukocyte populations by their size (forward scatter), granularity (side scatter), and auto-fluorescence, as previously described (Lun et al., 2007).

Lactation, Feed Intake, Production, and Functional Traits. A phenotypic data set was created and matched to the immune profile of each individual animal if IA trait information was available. This data contained lactation traits recorded at the daily level and included milk yield $(\mathrm{kg})$, fat and protein percentage $(\%)$, feed intake $(\mathrm{kg})$, DMI $(\mathrm{kg})$, feed-to-milk ratio, DM-to-milk ratio, empty $\mathrm{BW}(\mathrm{kg})$, live weight $(\mathrm{kg})$, BCS (0 to 5$)$, and SCC $\left(\times 10^{3} / \mathrm{mL}\right)$. Daily records were averaged over the week to give data for each week in milk. Information relating to record date (year, month), calving date (year, month), age at calving (months), Holstein percentage, lactation number, number of weeks in milk (WIM), diet group, and genetic group were also included. Information relating to the biological limits applied to the lactation data is presented in Supplemental Table S1 (https://doi.org/10.3168/ jds.2016-11679).

Health Traits. Detailed health records were available for each cow in the study population. A phenotypic data set containing health event information (expressed as binary traits) was created and matched to the immune profile of each individual animal. Health events were grouped into 4 groups: mastitis, reproductive problems, lameness, and other. Due to the low incidence of metabolic and other disorders or diseases within the Crichton herd these conditions (including ketosis, displaced abomasum, hypocalcemia, hypomagnesemia, pyelonephritis, and so on) were grouped into the other health category. Health events were then matched such that animals were scored as 0 or 1 for absence or presence of a condition or treatment within \pm 1 wk of the immune sample date. Additionally, the number of distinct mastitis, reproductive, and lameness episodes per lactation was calculated for each animal. Distinct episodes were calculated according to consecutive treatments more than 7,21 , and $28 \mathrm{~d}$ apart for mastitis, reproductive problems, and lameness, respectively (Banos et al., 2013).

Fertility Traits. A fertility timeline was created for each animal and included information for each lactation, such as calving date, calving interval, days to first heat, days from first to last heat, number of heats, days to first service, days from first to second service, days from first to last service, number of services, dystocia, and stillbirth rate. This information was matched to each cow's immune profile in the lactation the cow was sampled for immunological analysis. Calving interval 
referred to the interval between the date of calving of the previous lactation and the current calving. Number of services referred to the total number of AI before positive conception. Dystocia and stillbirth referred to the calving previous to the current lactation and were expressed as binary $(0 / 1)$ traits. Dystocia was scored as of 0 for a normal calving else 1 and stillbirth was scored as 0 if calves were born alive and 1 if born dead (or died within $24 \mathrm{~h}$ ).

\section{Statistical Analysis}

Statistical analysis of cellular IA traits was carried out using a repeated measures mixed linear animal model with a pedigree relationship matrix fitted to account for the genetic relationships between animals:

$$
\begin{aligned}
y_{i j k l m n o p q}= & \mu+F_{j}+G_{k}+W_{m}+T_{n}+Y_{q}+L_{l} \\
& +C_{i}+a_{o}+p_{o}+e_{i j k l m n o p q},
\end{aligned}
$$

where $y_{i j k l m n o p q}$ is the trait record; $\mu$ is the overall mean; $F_{j}$ is the fixed effect of the $j$ th diet group; $G_{k}$ is the fixed effect of the $k$ th genetic group; $W_{m}$ is the fixed effect of the $m$ th lactation week; $T_{n}$ is the fixed effect of the $n$th assay technique, fitted to account for the variation between the methods used to generate the IA trait data; $Y_{q}$ is the fixed effect of the qth year by month of record interaction; $L_{l}$ is the fixed effect of the lth lactation number by age at calving; $C_{i}$ is the fixed effect of the $i$ th year by month of calving interaction; $a_{o}$ is the random additive genetic effect of the oth individual cow including pedigree data (2,793 animal in pedigree, see Table 1 for further details); $p_{o}$ is the random permanent environmental effect of the oth individual cow, fitted to account for the use of repeated measures of the same animal; and $e_{i j k l m n o p q}$ is the random residual effect.

Total phenotypic variances $\left(\sigma_{p}^{2}\right)$, as well as corresponding additive genetic $\left(\sigma_{a}^{2}\right)$, permanent environmen- tal $\left(\sigma_{p e}^{2}\right)$, and residual $\left(\sigma_{e}^{2}\right)$ variance and covariance components were estimated by the Restricted Maximum Likelihood (REML) approach using ASReml version 3 (Gilmour et al., 2009). Univariate models were run initially for each trait to establish the correct model (the significance levels of the fixed effects are presented in Supplemental Table S2; https://doi. org/10.3168/jds.2016-11679), followed by a series of bivariate models to estimate the genetic or phenotypic correlations between cellular IA traits and the health, fertility, and production traits. For all model outputs, $P$-values $<0.05$ were considered significant. The variance components were used in the calculation of the following genetic and phenotypic parameters: the ratio of total phenotypic variance attributed to additive genetic variation $\left(\mathrm{h}^{2}\right)$; the ratio of total phenotypic variance due to the individual animal (sum of additive genetic and permanent environmental effects; i.e., between-individual variation; repeatability, $\mathbf{R}$ ); and the ratio of total phenotypic variance due to permanent environmental variance $\left(\mathbf{c}^{2}\right)$.

\section{RESULTS}

The data used in our study are summarized in Table 2 (IA traits), Table 3 (production and functional traits), and Table 4 (health and fertility traits). Coefficients of variation of the traits were substantial and ranged from 18 (\% PBMC) to 95\% (\% eosinophils) for IA traits; 12 (protein \%) to $318 \%$ (SCC) for production and functional traits; and 18 (calving interval) to $113 \%$ (days first to last service) for fertility traits. The coefficient of variation was used as an indicator of trait variability, and, as seen above, marked differences in variability among recorded traits was observed.

Total phenotypic variances $\left(\sigma_{p}^{2}\right)$, as well as corresponding additive genetic $\left(\sigma_{a}^{2}\right)$, permanent environmental $\left(\sigma_{p e}^{2}\right)$, and residual $\left(\sigma_{e}^{2}\right)$ variance components and

\begin{tabular}{|c|c|c|c|c|c|c|}
\hline Trait & No. of records & Minimum & Maximum & Mean & $\mathrm{SD}$ & $\mathrm{CV}(\%)$ \\
\hline$\% \mathrm{PBMC}^{1,2}$ & 2,266 & 18.00 & 89.50 & 58.39 & 10.24 & 17.54 \\
\hline$\%$ Eosinophils ${ }^{2}$ & 2,266 & 0.07 & 35.20 & 3.61 & 3.43 & 95.06 \\
\hline$\%$ Lymphocytes $^{2}$ & 2,265 & 7.70 & 79.70 & 44.25 & 12.35 & 27.90 \\
\hline$\%$ Monocytes $^{2}$ & 2,265 & 3.03 & 55.40 & 13.99 & 8.25 & 58.98 \\
\hline$\%$ Neutrophils ${ }^{2}$ & 2,266 & 8.09 & 81.10 & 37.76 & 10.10 & 26.74 \\
\hline$\% \mathrm{CD}^{+3}$ & 2,232 & 3.39 & 46.00 & 25.52 & 6.28 & 24.61 \\
\hline$\% \mathrm{CD}^{+3}$ & 2,260 & 2.51 & 28.00 & 11.29 & 3.42 & 30.28 \\
\hline $\mathrm{CD}^{+}: \mathrm{CD}^{+}$ratio & 2,232 & 0.48 & 6.12 & 2.38 & 0.73 & 30.67 \\
\hline$\% \mathrm{NKp} 46^{+3}$ & 2,262 & 0.01 & 16.50 & 2.32 & 1.58 & 67.95 \\
\hline
\end{tabular}

Table 2. Descriptive statistics of the 9 cellular immune-associated traits obtained via flow cytometric analysis

$1 \%$ peripheral blood mononuclear cells.

${ }^{2} \%$ of total leukocytes that were PBMC, eosinophils, lymphocytes, monocytes, or neutrophils.

$3 \%$ of PBMC that were positive for CD4, CD8, and NKp46. 
DENHOLM ET AL.

Table 3. Descriptive statistics of the 12 production and functional traits

\begin{tabular}{lcrrrrr}
\hline Trait & No. of records & Minimum & Maximum & Mean & \multicolumn{1}{c}{ SD } & CV (\%) \\
\hline Milk (kg) & 90,750 & 3.00 & 65.54 & 28.71 & 9.10 & 31.71 \\
Fat (\%) & 72,433 & 0.23 & 9.94 & 3.78 & 0.71 & 18.83 \\
Protein (\%) & 72,433 & 0.20 & 6.65 & 3.21 & 0.39 & 12.00 \\
Feed intake (kg) & 64,970 & 2.21 & 182.31 & 42.39 & 11.71 & 27.63 \\
DMI (kg) & 64,970 & 1.03 & 57.27 & 16.62 & 5.22 & 31.39 \\
ME intake (MJ) & 64,970 & 10.47 & 641.47 & 186.56 & 59.15 & 31.70 \\
Empty BW (kg) & 88,345 & 237.00 & 782.00 & 483.00 & 67.50 & 13.98 \\
Live weight (kg) & 88,345 & 310.00 & 953.00 & 605.00 & 79.51 & 13.14 \\
BCS (0-5) & 69,703 & 0.50 & 4.25 & 2.11 & 0.43 & 20.33 \\
SCC (×10 $/ \mathrm{mL})$ & 74,288 & 2.67 & $7,865.00$ & 110.64 & 351.76 & 317.93 \\
Feed intake:milk & 64,919 & 0.07 & 271.50 & 1.61 & 1.98 & 122.92 \\
DMI:milk & 64,919 & 0.03 & 136.56 & 0.62 & 0.84 & 135.82 \\
\hline
\end{tabular}

their standard errors, were estimated and are presented in Table 5. Estimates of heritability, between-individual variation $(\mathrm{R})$, and the ratio of total phenotypic variance due to permanent environmental variance $\left(\mathrm{c}^{2}\right)$ are also presented in Table 5 . Statistically significant $(P<$ $0.05)$ heritability estimates were obtained for all 9 IA traits. Heritability estimates ranged from 0.15 (\% monocytes) to $0.46\left(\% \mathrm{CD}^{+}\right)$, with the majority above 0.2 . The highest heritabilities were observed in the $\mathrm{T}$ cell and NK cell subsets $\left(\% \mathrm{CD} 4^{+}, \% \mathrm{CD} 8^{+}, \mathrm{CD} 4^{+}: \mathrm{CD} 8^{+}\right.$ ratio, and $\% \mathrm{NKp} 46^{+} ; 0.46,0.41,0.43$, and 0.42 , respectively; Table 5). Significant heritability estimates suggest these traits could be improved with selective breeding.

All IA traits were shown to be repeatable, and between-animal variation accounted for 18 to $81 \%$ of total phenotypic variance (Table 5 ). The most significant estimates of repeatability were observed in percent $\mathrm{CD} 4^{+}$, percent $\mathrm{CD} 8^{+}, \mathrm{CD} 4^{+}: \mathrm{CD} 8^{+}$ratio, and percent $\mathrm{NKp} 46^{+}$ $(0.70,0.76,0.81$, and 0.59 , respectively; Table 5).
The permanent environmental effect was fitted to estimate any between-animal variation over and above that due to additive genetic effects. This could be due to long-term environmental effects (e.g., previous diseases) or nonadditive genetic effects (e.g., epigenetic) that pertain to individual animals throughout their lives but are not passed on to the next generation. A significant ratio of total phenotypic variance due to permanent environmental variance $\left(c^{2}\right)$ was found for percent eosinophils, percent $\mathrm{CD} 4^{+}$, percent $\mathrm{CD} 8^{+}$, $\mathrm{CD} 4^{+}: \mathrm{CD}^{+}$ratio, and percent $\mathrm{NKp}^{+} 6^{+}(0.22,0.23$, $0.34,0.38$, and 0.17 , respectively). For all traits, with the exception of percent eosinophils, estimates for $\mathrm{c}^{2}$ were lower than the heritability. Moreover, all traits appeared to show higher genetic variances in comparison with permanent environmental variances $(\%$ eosinophils once again being the only exception). In the case of percent PBMC, percent eosinophils, percent lymphocytes, percent monocytes, and percent neutrophils, the largest proportion of phenotypic variance was

Table 4. Descriptive statistics of the health traits and fertility traits

\begin{tabular}{|c|c|c|c|c|c|c|c|c|}
\hline Item & No. of records & Minimum & Maximum & Incidence $^{1}$ & Mean $^{2}$ & $\mathrm{SD}^{2}$ & Maximum $^{2}$ & $\mathrm{CV}(\%)$ \\
\hline \multicolumn{9}{|l|}{ Health trait } \\
\hline Mastitis & & & & 0.01 & 0.17 & 0.38 & 10 & \\
\hline \multicolumn{9}{|l|}{ Fertility trait } \\
\hline Calving interval (d) & 663 & 189 & 737 & & 404.41 & 74.15 & & 18.34 \\
\hline Days to first heat (d) & 855 & 2 & 205 & & 58.64 & 30.68 & & 52.32 \\
\hline Days to first service (d) & 850 & 4 & 205 & & 66.66 & 25.95 & & 38.92 \\
\hline Days first second service (d) & 634 & 1 & 206 & & 33.71 & 24.13 & & 71.58 \\
\hline Days first last service (d) & 850 & 0 & 662 & & 75.72 & 85.68 & & 113.15 \\
\hline Number of services & 861 & 0 & 14 & & 3.41 & 2.65 & & 77.70 \\
\hline Dystocia score $(0 / 1)$ & 861 & - & - & & 0.22 & 0.41 & & - \\
\hline Stillbirth score $(0 / 1)$ & 861 & - & - & & 0.09 & 0.29 & & - \\
\hline
\end{tabular}

${ }^{1}$ Proportion of cows experiencing a health event on the week of immune sampling. Measured as a binary trait.

${ }^{2}$ Based on number of distinct episodes per lactation. 
Table 5. Results from univariate analysis ${ }^{1}$

\begin{tabular}{|c|c|c|c|c|c|c|c|}
\hline Trait & $\sigma_{a}^{2}$ & $\sigma_{p e}^{2}$ & $\sigma_{e}^{2}$ & $\sigma_{p}^{2}$ & $h^{2}$ & $c^{2}$ & $\mathrm{R}$ \\
\hline$\% \mathrm{PBMC}^{2,3}$ & $\begin{array}{c}\mathbf{2 2 . 4 5} \\
(5.828)\end{array}$ & $\begin{array}{l}3.21 \\
(3.997)\end{array}$ & $\begin{array}{c}\mathbf{5 0 . 4 2} \\
(1.725)\end{array}$ & $\begin{array}{c}\mathbf{7 6 . 0 8} \\
(3.510)\end{array}$ & $\begin{array}{l}\mathbf{0 . 3 0} \\
(0.065)\end{array}$ & $\begin{array}{l}0.04 \\
(0.053)\end{array}$ & $\begin{array}{l}\mathbf{0 . 3 4} \\
(0.030)\end{array}$ \\
\hline$\%$ Eosinophils $^{3}$ & $\begin{array}{l}\mathbf{1 . 1 8} \\
(0.490)\end{array}$ & $\begin{array}{l}\mathbf{1 . 5 6} \\
(0.423)\end{array}$ & $\begin{array}{l}\mathbf{4 . 4 1} \\
(0.151)\end{array}$ & $\begin{array}{l}\mathbf{7 . 1 6} \\
(0.320)\end{array}$ & $\begin{array}{l}\mathbf{0 . 1 7} \\
(0.065)\end{array}$ & $\begin{array}{c}\mathbf{0 . 2 2} \\
(0.059)\end{array}$ & $\begin{array}{l}\mathbf{0 . 3 8} \\
(0.028)\end{array}$ \\
\hline \% Lymphocytes ${ }^{3}$ & $\begin{array}{c}\mathbf{2 3 . 6 6} \\
(5.655)\end{array}$ & $\begin{array}{l}0.22 \\
(3.679)\end{array}$ & $\begin{array}{l}\mathbf{4 4 . 6 0} \\
(1.563)\end{array}$ & $\begin{array}{c}\mathbf{6 8 . 4 8} \\
(3.331)\end{array}$ & $\begin{array}{l}\mathbf{0 . 3 5} \\
(0.071)\end{array}$ & $\begin{array}{l}0.00 \\
(0.054)\end{array}$ & $\begin{array}{l}\mathbf{0 . 3 5} \\
(0.032)\end{array}$ \\
\hline$\%$ Monocytes $^{3}$ & $\begin{array}{l}\mathbf{1 . 1 9} \\
(0.416)\end{array}$ & $\begin{array}{l}0.29 \\
(0.327)\end{array}$ & $\begin{array}{l}\mathbf{6 . 5 2} \\
(0.227)\end{array}$ & $\begin{array}{l}\mathbf{8 . 0 0} \\
(0.298)\end{array}$ & $\begin{array}{l}\mathbf{0 . 1 5} \\
(0.049)\end{array}$ & $\begin{array}{l}0.04 \\
(0.041)\end{array}$ & $\begin{array}{l}\mathbf{0 . 1 8} \\
(0.026)\end{array}$ \\
\hline$\%$ Neutrophils $^{3}$ & $\begin{array}{c}\mathbf{2 0 . 6 2} \\
(5.403)\end{array}$ & $\begin{array}{l}3.42 \\
(3.766)\end{array}$ & $\begin{array}{l}\mathbf{5 1 . 8 0} \\
(1.772)\end{array}$ & $\begin{array}{c}\mathbf{7 5 . 8 5} \\
(3.369)\end{array}$ & $\begin{array}{l}\mathbf{0 . 2 7} \\
(0.064)\end{array}$ & $\begin{array}{l}0.05 \\
(0.050)\end{array}$ & $\begin{array}{l}\mathbf{0 . 3 2} \\
(0.030)\end{array}$ \\
\hline$\% \mathrm{CD}^{+4}$ & $\begin{array}{l}\mathbf{8 . 4 9} \\
(2.258)\end{array}$ & $\begin{array}{c}\mathbf{4 . 2 6} \\
(1.531)\end{array}$ & $\begin{array}{c}\mathbf{5 . 5 6} \\
(0.193)\end{array}$ & $\begin{array}{c}\mathbf{1 8 . 3 1} \\
(1.261)\end{array}$ & $\begin{array}{l}\mathbf{0 . 4 6} \\
(0.101)\end{array}$ & $\begin{array}{c}\mathbf{0 . 2 3} \\
(0.090)\end{array}$ & $\begin{array}{l}\mathbf{0 . 7 0} \\
(0.023)\end{array}$ \\
\hline$\% \mathrm{CD}^{+4}$ & $\begin{array}{l}\mathbf{4 . 1 4} \\
(1.126)\end{array}$ & $\begin{array}{l}\mathbf{3 . 4 4} \\
(0.828)\end{array}$ & $\begin{array}{l}\mathbf{2 . 4 5} \\
(0.085)\end{array}$ & $\begin{array}{c}\mathbf{1 0 . 0 4} \\
(0.677)\end{array}$ & $\begin{array}{l}\mathbf{0 . 4 1} \\
(0.095)\end{array}$ & $\begin{array}{l}\mathbf{0 . 3 4} \\
(0.088)\end{array}$ & $\begin{array}{l}\mathbf{0 . 7 6} \\
(0.018)\end{array}$ \\
\hline $\mathrm{CD} 4^{+}: \mathrm{CD} 8^{+4}$ & $\begin{array}{l}\mathbf{0 . 2 1} \\
(0.066)\end{array}$ & $\begin{array}{l}\mathbf{0 . 1 9} \\
(0.048)\end{array}$ & $\begin{array}{l}\mathbf{0 . 1 0} \\
(0.003)\end{array}$ & $\begin{array}{c}\mathbf{0 . 5 0} \\
(0.036)\end{array}$ & $\begin{array}{l}\mathbf{0 . 4 3} \\
(0.112)\end{array}$ & $\begin{array}{c}\mathbf{0 . 3 8} \\
(0.105)\end{array}$ & $\begin{array}{l}\mathbf{0 . 8 1} \\
(0.015)\end{array}$ \\
\hline$\% \mathrm{NKp} 46^{+4}$ & $\begin{array}{l}\mathbf{0 . 5 5} \\
(0.135)\end{array}$ & $\begin{array}{c}\mathbf{0 . 2 2} \\
(0.092)\end{array}$ & $\begin{array}{l}\mathbf{0 . 5 5} \\
(0.019)\end{array}$ & $\begin{array}{l}\mathbf{1 . 3 3} \\
(0.080)\end{array}$ & $\begin{array}{l}\mathbf{0 . 4 2} \\
(0.085)\end{array}$ & $\begin{array}{l}\mathbf{0 . 1 7} \\
(0.073)\end{array}$ & $\begin{array}{l}\mathbf{0 . 5 9} \\
(0.027)\end{array}$ \\
\hline
\end{tabular}

${ }^{1}$ Additive genetic $\left(\sigma_{a}^{2}\right)$, permanent environmental $\left(\sigma_{p e}^{2}\right)$, residual $\left(\sigma_{e}^{2}\right)$, and phenotypic variances $\left(\sigma_{p}^{2}\right)$, with standard errors in parentheses, are presented for the 9 cellular immune-associated traits. Heritability estimates $\left(h^{2}\right)$, ratio of permanent environmental variance $\left(c^{2}\right)$ and repeatability $(R)$, with standard errors, are also provided. Statistically significant values $(P<0.05)$ are given in bold.

${ }^{2} \%$ peripheral blood mononuclear cells.

${ }^{3} \%$ of total leukocytes that were PBMC, eosinophils, lymphocytes, monocytes or neutrophils.

${ }^{4} \%$ of PBMC that were positive for CD4, CD8, and NKp46.

observed in the residual variance (Table 5). Significant repeatability estimates may help to derive predictions of future animal performance. No significant estimates of $\mathrm{c}^{2}$ were obtained for the remaining traits, which may be a function of data set size.

Additive genetic correlations between traits of interest to our study are presented in Tables 6 and 7 along with their corresponding standard errors; informative phenotypic correlations are presented in Table 8. Less informative phenotypic correlations, as well as permanent environmental and residual correlations, are summarized in Supplemental Tables S3 to S4, S5 to S6, and S7 to S8 (https://doi.org/10.3168/jds.2016-11679), respectively.

Milk fat percentage was found to have a moderate positive genetic correlation with percent PBMC (0.33) and percent lymphocytes (0.36), and a negative association with neutrophils $(-0.35)$. Moderate negative genetic correlations were found between the $\mathrm{CD} 4^{+}: \mathrm{CD} 8^{+}$ratio within the PBMC population and live weight $(-0.52)$ and, similarly, empty BW $(-0.52)$. Further significant genetic correlations were between IA and feed conversion traits; these were low to moderate and are presented in Table 6. Regarding fertility traits (Table 7), significant correlations were observed between percent $\mathrm{NKp} 46^{+}$and stillbirth rate (0.61). Analyses yielded no significant correlations with health traits (Table 7); however, the following relationships were found to be approaching significance (i.e., $0.5<P$
$<0.1$ ), highlighting the requirement for further investigation: lameness episodes and percent $\mathrm{CD}^{+}(-0.51, P$ $=0.06)$; lameness episodes and $\mathrm{CD} 4^{+}: \mathrm{CD} 8^{+}$ratio $(0.47$, $P=0.08)$; and mastitis and percent eosinophils (0.63, $P=0.09)$.

The largest significant phenotypic correlations (Table 8) estimated between IA and production traits were all negative and were between the $\mathrm{CD} 4^{+}: \mathrm{CD} 8^{+}$ratio and live weight, empty BW, and BCS $(-0.16,-0.15$, and -0.11 , respectively). For the fertility traits, a negative association between percent $\mathrm{CD} 4^{+}$and time between first and second service was identified $(-0.14)$ as well as a positive relationship between percent monocytes and calving interval (0.10). The remaining phenotypic correlations where close to zero and are summarized in Supplemental Tables S3 (production and functional traits) and S4 (fertility and health; https://doi. org/10.3168/jds.2016-11679).

Regarding production and functional traits, the only statistically significant permanent environmental correlations were moderate, negative, and between percent eosinophils and milk yield $(-0.47)$, feed intake $(-0.50)$, DMI (-0.52), and ME intake (-0.53). Additionally, percent $\mathrm{CD} 4^{+}$was found to be negatively correlated with BCS $(-0.43)$. In the health traits, a negative association between percent eosinophils and reproductive episodes $(-0.25)$ as well as a positive association between percent $\mathrm{CD} 4^{+}$and mastitis $(0.30)$ were noted. Finally, in the case of the fertility traits, permanent 
DENHOLM ET AL.

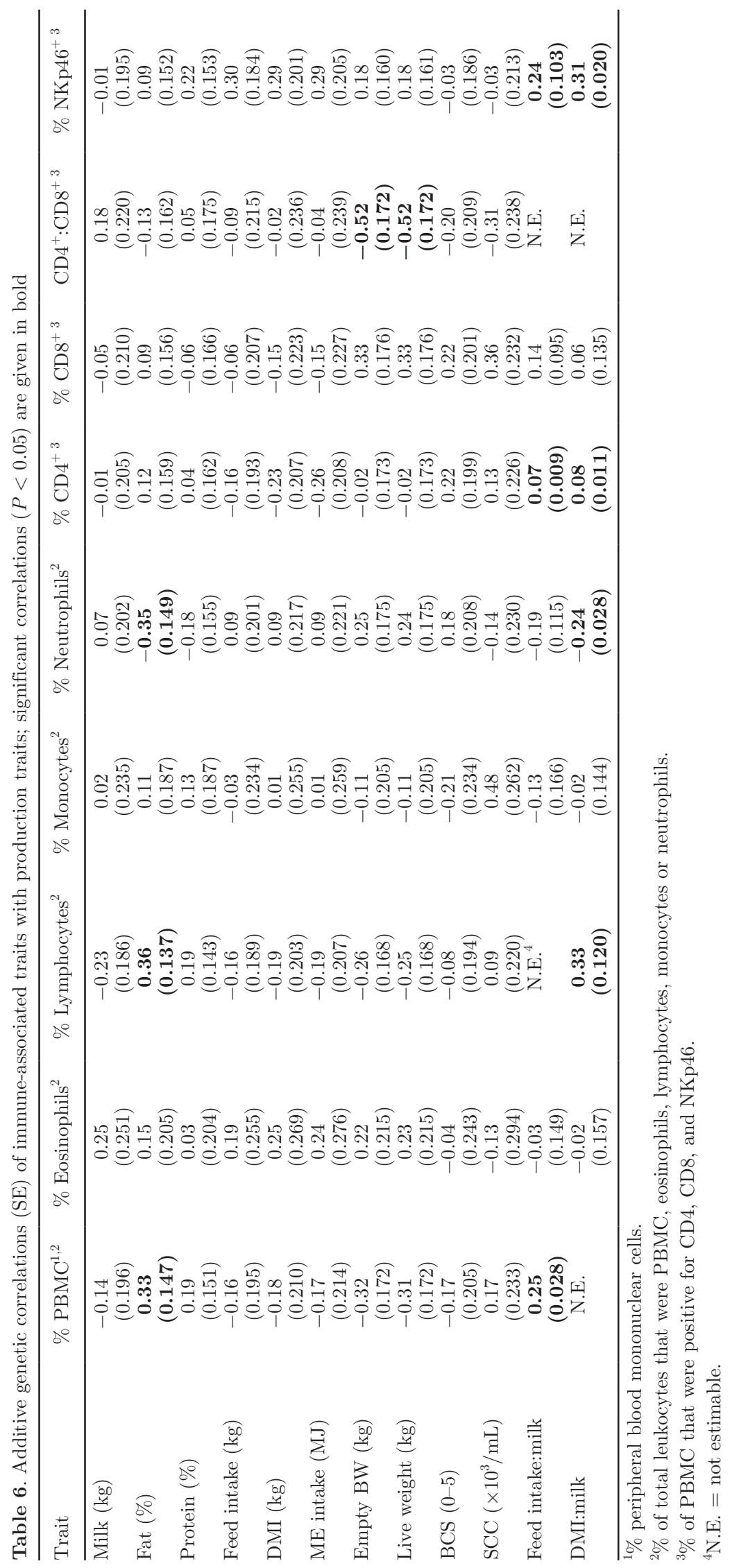




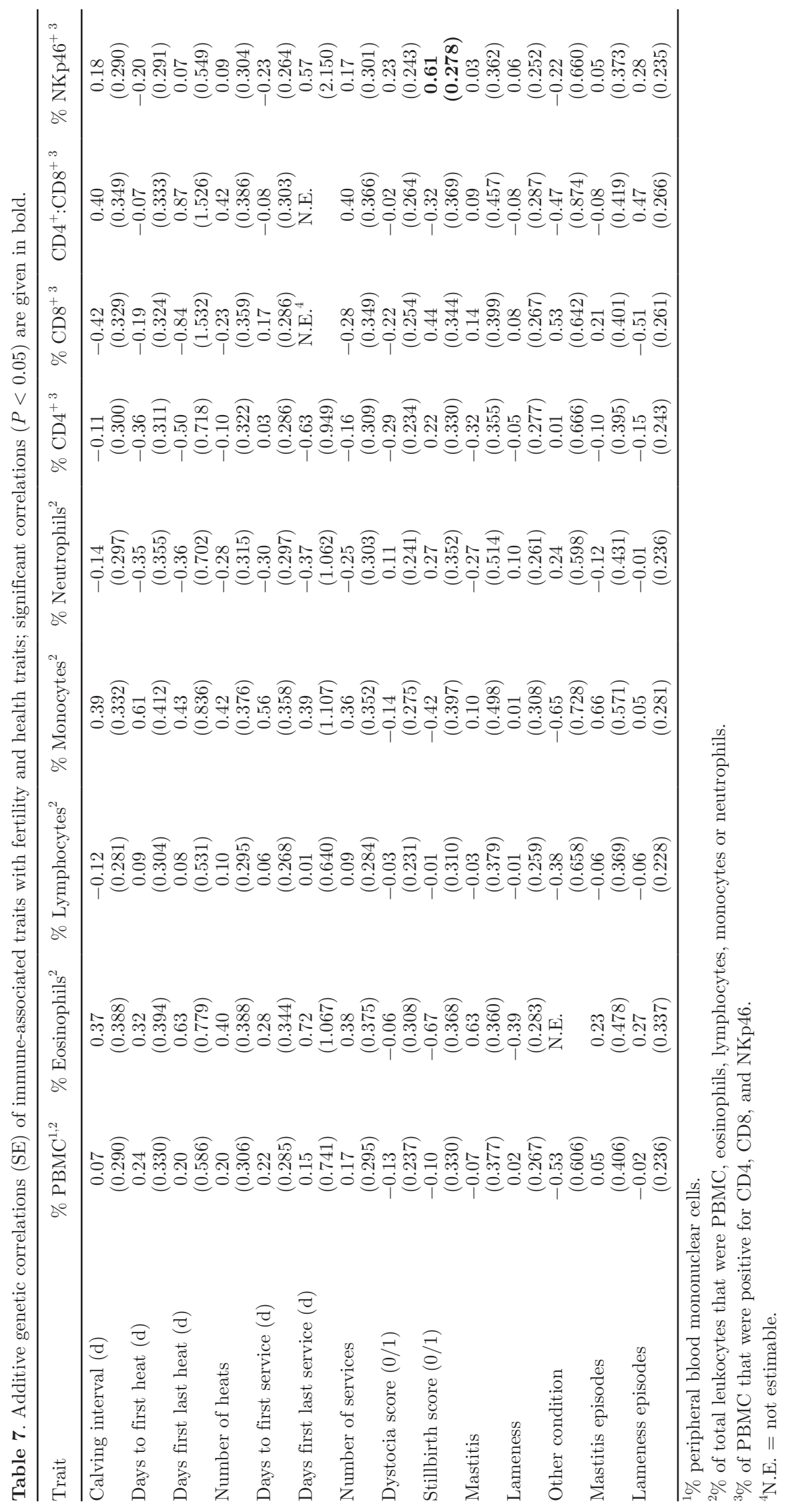


Table 8. Phenotypic correlations $(\mathrm{SE})$ of immune-associated traits with production, health, and fertility traits; significant correlations $(P<$ $0.05)$ are given in bold

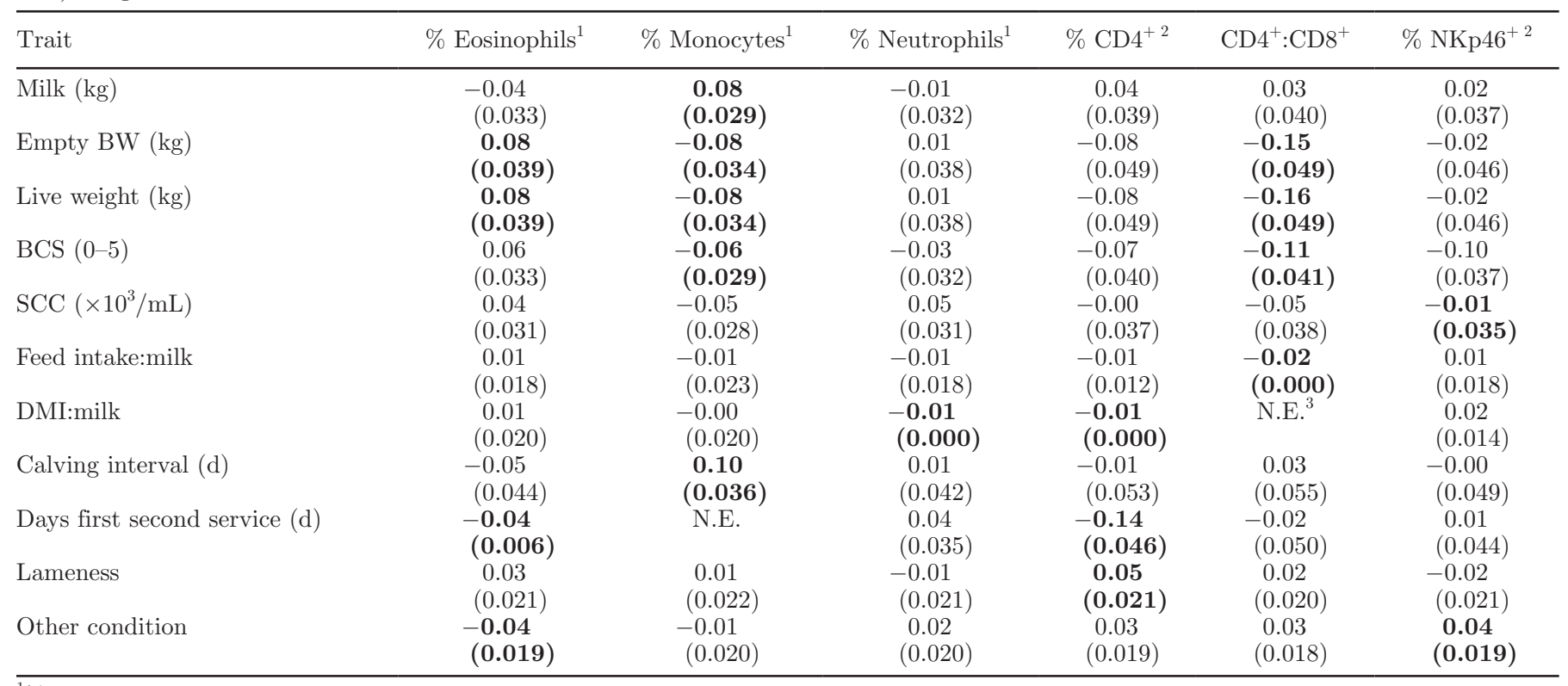

$1 \%$ of total leukocytes that were eosinophils, monocytes or neutrophils.

${ }^{2} \%$ of peripheral blood mononuclear cells that were positive for CD4, CD8, and NKp46.

${ }^{3}$ N.E. $=$ not estimable.

environmental correlations were found to be moderate and negative between $\mathrm{CD} 4^{+}: \mathrm{CD} 8^{+}$ratio and number of heats or services $(-0.25$ and -0.27 , respectively). Moreover, positive relationships where found to exist between percent $\mathrm{CD} 8^{+}$and number of services, number of heats, and the time between first and last service $(0.26,0.23$, and 0.23 , respectively). Permanent environmental correlations may be used to develop optimal management practices regarding future animal performance (see Supplemental Tables S5 to S6 for production, fertility, and health traits, respectively; https:// doi.org/10.3168/jds.2016-11679). Residual correlations (i.e., correlations which relate to covariation unexplained by the model of analysis) were generally low or close to zero in all traits (see Supplemental Tables S7 to S8; https://doi.org/10.3168/jds.2016-11679).

\section{DISCUSSION}

Previously, Thompson-Crispi et al. (2012b) showed antibody- and cell-mediated immune response traits in Holstein-Friesian dairy cows to be heritable, with estimates of 0.29 and 0.19 , respectively, which was further confirmed by Heriazon et al. (2013); however, these studies focused on immune response traits rather than the steady state measured IA traits presented here. In the present study, significant genetic and phenotypic associations were observed between $\mathrm{T}$ cell subsets and fertility as well as lameness events. T cell subsets, such as CD4 T helper cells, produce cytokines and chemokines and play an important role in immune protection, interacting with many other immune cells, such as B cells, eosinophils, basophils macrophages, and neutrophils (Zhu and Paul, 2008). Earlier work by Saama et al. (2004) also highlighted the potential importance lymphocyte subsets as indicators of immune competence in dairy cattle. As highlighted above, the $\mathrm{T}$ cell subsets showed the most promising heritabilities, which were consistent with previous studies (Saama et al., 2004; Clapperton et al., 2009). Specifically, heritability of percent $\mathrm{CD}^{+}$has been previously reported as 0.69 in pigs (Clapperton et al., 2009); moreover, Ahmadi et al. (2001) reported a heritability of 0.54 in humans. Ahmadi et al. (2001) measured actual $\mathrm{CD} 4^{+}$cell counts in contrast to $\mathrm{CD}^{+}$measured as a proportion of PBMC (i.e., \% CD4 ${ }^{+}$) as in Clapperton et al. (2009) and the present study. Comparison of the genetic variance estimates from all 3 studies suggests they are similar regardless of whether total numbers or proportions are used, presumably as the numbers of PBMC per milliliter of blood are not changing considerably between individuals.

Previously, $\mathrm{CD} 4^{+}: \mathrm{CD} 8^{+}$ratio was shown to have a negative phenotypic correlation with milk SCC in cows $(-0.56$, Banos et al., 2013). The present study estimated a genetic correlation between $\mathrm{CD} 4^{+}: \mathrm{CD} 8^{+}$and 
SCC of $-0.31(P=0.17)$. The present study used a much larger data set (4-fold increase in IA records), collected over a longer period, and incorporated the original data collected previously (Banos et al., 2013). Although not significant, the results suggest, at a genetic level, animals with lower values of $\mathrm{CD} 4^{+}: \mathrm{CD} 8^{+}$ ratios will have higher SCC. Moreover, a high SCC in milk is often considered as an indicator of mastitis and other IMI in cattle (Mrode and Swanson, 1996, 2003); many countries currently use SCC (or SCS) to indirectly breed for mastitis resistance (Miglior et al., 2005). In the present study, the genetic correlation between SCC and mastitis was 0.67 , with a corresponding phenotypic correlation of 0.12 . A lower value of $\mathrm{CD}^{+}: \mathrm{CD} 8^{+}$can be indicative of a chronic infection and a higher value indicative of fighting a major or viral infection. A low $\mathrm{CD} 4^{+}: \mathrm{CD} 8^{+}$ratio may potentially indicate the presence of mastitis infection, either by sequestering circulating $\mathrm{CD} 4^{+} \mathrm{T}$ cells into the mammary gland (e.g., Taylor et al., 1997; Tassi et al., 2013), or preferentially expanding both circulatory and mammary populations of $\mathrm{CD} 8^{+}$ $\mathrm{T}$ cells, as these have been shown to play a key role in protection against IMI (Denis et al., 2011). Evidence of such an association has also been reported (Park et al., 2004).

Additionally, the $\mathrm{CD} 4^{+}: \mathrm{CD} 8^{+}$ratio, a cell-mediated adaptive IA trait that decreases with age (Wikby et al., 1998; Hadrup et al., 2006; Strindhall et al., 2007), has been found to exhibit a high level of heritability across species; for example, 0.65 in humans (Hall et al., 2000) and 0.64 in pigs (Flori et al., 2011a). The CD $4^{+}$cells are associated with fighting against infections, whereas the $\mathrm{CD} 8^{+}$cells are killer cells of the immune system. The $\mathrm{CD}^{+}: \mathrm{CD}^{+}$ratio gives an indication of the strength of the immune system such that declining ratios are associated with immune dysfunction and increased risks of severe infections and malignancies (Wikby et al., 1998; Strindhall et al., 2007; Lu et al., 2015). In humans, the $\mathrm{CD} 4^{+}: \mathrm{CD}^{+}$ratio can be used as a marker of human immunodeficiency virus to acquired immunodeficiency syndrome progression (Fahey et al., 1990; SerranoVillar et al., 2015). Other human health conditions that have been previously associated with the $\mathrm{CD} 4^{+}: \mathrm{CD} 8^{+}$ ratio include chronic lymphocytic leukemia (Bartik et al., 1998; Gonzalez-Rodriguez et al., 2010), infectious mononucleosis and other viral infections (Karcheva et al., 2008; Salih, 2009), Hodgkin disease (Gupta, 1980; Poppema, 1996; Gorczyca et al., 2002; Hernandez et al., 2005), aplastic anemia (Zhang et al., 2007), as well as neurological disorders such as multiple sclerosis (Pender et al., 2014) and myasthenia gravis (Berrih et al., 1981; Matsui and Kameyama, 1986). Further, substantial evidence exists that this trait is under genetic control in mice, chickens, and humans (Kraal et al., 1983; Clementi et al., 1999; Amadori et al., 1995; Myrick et al., 2002; Ewald et al., 1996).

The present study also identified a moderately strong genetic correlation between $\mathrm{CD} 4^{+}: \mathrm{CD}^{+}$ratio and lameness $(0.51, P=0.06)$, which was only identified at the phenotypic level in our previous study (Banos et al., 2013). This suggests that animals with higher steady-state values of $\mathrm{CD}^{+}: \mathrm{CD} 8^{+}$ratios are genetically predisposed to higher incidences of lameness. Additional moderate genetic correlations were found between SCC and $\mathrm{CD}^{+}(0.36, P=0.12)$ and monocytes $(0.48$, $P=0.08)$, but were not statistically significant. As $\mathrm{CD}^{+}: \mathrm{CD}^{+}$is useful in particular types of infections, it would be interesting to explore if the relationship is consistent with different mastitis or lameness causing pathogens and duration of said health events.

A strong genetic correlation was found between percent NKp46 ${ }^{+}$, a natural killer (NK) cell marker, (Sivori et al., 1997; Storset et al., 2004) and stillbirth (0.61, $P=$ $0.04)$, which is a novel finding in cattle. This is in agreement with literature concerning human studies, which have consistently identified a relationship between NK cells and reproductive outcomes, with higher percentages of NK cells within the circulating lymphocyte pool being associated with poor reproduction (Michou et al., 2003; Kwak-Kim and Gilman-Sachs, 2008; King et al., 2010; Seshadri and Sunkara, 2014). Natural killer cells are a type of innate immune cell with potent cytotoxic activity that are important in controlling intracellular pathogens (Storset et al., 2004). Circulating NK cells can traffic into the uterus, and their association with reproductive failure is thought to be due to unregulated NK-mediated cytotoxicity within the uterine environment (Kwak-Kim and Gilman-Sachs, 2008).

Previous research has demonstrated that the occurrence of metabolic and infectious disease in dairy cows classed as high immune responding is lower than non-high-immune responding cows (Thompson-Crispi et al., 2012a, 2013). Results from the present study support opinions in the literature that genetic selection of measurable immune-associated phenotypes may be possible (Thompson-Crispi et al., 2012b; Heriazon et al., 2013), could provide a useful tool in monitoring and improving disease resistance and animal health (Mallard et al., 2011, 2015; Thompson-Crispi et al., 2014a), and may not negatively affect production (Stoop et al., 2016). Results also highlight the importance of blood leukocyte subsets with respect to reproduction and fertility in dairy cows; the strong association found between stillbirth and percent $\mathrm{NKp} 46^{+}$is promising and gives a foundation for further investigation.

One limitation of the current study is that no functional assessment has been performed on the various leukocyte subsets measured. Many of these subsets 
exhibit a wide range of functional capabilities, which will be related to their previous antigenic experience (particularly for lymphocyte subsets) or other environmental and host factors (e.g., nutritional, reproductive, or disease status). For example, whereas $\mathrm{CD} 8^{+} \mathrm{T}$ cells largely target intracellular pathogens through killing of infected cells and production of antiviral cytokines (Bevan, 2004), CD4 ${ }^{+} \mathrm{T}$ cells differentiate into several distinct helper- $\mathrm{T}$ cell subsets including T-helper $\left(\mathrm{T}_{\mathrm{H}}\right)-1$, $\mathrm{T}_{\mathrm{H}^{-}} 2, \mathrm{~T}_{\mathrm{H}^{-}} 9, \mathrm{~T}_{\mathrm{H}^{-}}-17$, and regulatory $\mathrm{T}$ cells, all of which exhibit different functionalities in relation to the types of pathogens they target or their role in regulating the immune response (Nakayamada et al., 2012). Thus, associations between the cellular traits used in our study and health traits may be weaker or absent in other study populations, and, consequently, the health benefits of selection for these cellular traits in dairy cattle may be unpredictable. In future studies, IA traits involving additional cellular markers or immune assays that better reflect immune function (e.g., naïve vs. memory $\mathrm{T}$ cell markers, cytokine release profiles) should be explored. Such an approach would be similar to, but less labor intensive than, that taken by other studies (ThompsonCrispi et al., 2013, 2014a), in which proposed selection is based on antibody-mediated immune response traits (broadly representing $\mathrm{T}_{\mathrm{H}^{-}} 2$ immunity) and cell-mediated immune response traits (broadly representing $\mathrm{T}_{\mathrm{H}^{-}}-1$ immunity) obtained following immunization of cattle with specific antigens.

In addition to the immunological measures of blood leukocyte subsets considered in the present study, serological immune phenotypes measurable in both bovine milk and blood may also be of value in improving the health and welfare of dairy cows. Associations between IA traits found in blood and milk have been highlighted, for example, in natural antibodies (de Klerk et al., 2015) and haptoglobin (Hiss et al., 2009). Furthermore, supporting the results of the present study, serological IA traits are considered beneficial and an association between haptoglobin and mastitis has previously been highlighted (Banos et al., 2013). Moreover, obtaining data collected with the research herd used in the present study would be advantageous and provide a means of validating our results.

In the present study, we have provided evidence that cellular IA traits derived from measurable blood leukocyte populations are heritable and would permit selection for altered trait values, particularly in the case of the $\mathrm{T}$ cell subsets. Moreover, the associations observed between IA, health, fertility, and production traits suggest that genetic selection for cellular IA traits could lead to a useful tool in improving animal health, fitness, and fertility.

\section{ACKNOWLEDGMENTS}

The authors express their gratitude to the Biotechnology and Biological Sciences Research Council (BBSRC, Swindon, UK) for funding this research (grant no. BB/ K002260/1). Additionally, the authors thank all staff at Crichton Farm (Dumfries, Scotland) for collecting and prompt transfer of the samples; Ian Archibald (SRUC, Edinburgh, Scotland) for managing the data and assisting with data extraction; and Raphael Mrode (SRUC, Edinburgh, Scotland) for statistical input. For the Langhill experiment at Crichton Dairy Research Centre, Eileen Wall, Tom McNeilly, and George Russell are supported by the Scottish Government Rural Affairs, Food and the Environment (RAFE, Edinburgh, Scotland) Strategic Research Portfolio 2016-2021.

\section{REFERENCES}

Abdel-Azim, G. A., A. E. Freeman, M. E. Kehrli, S. C. Kelm, J. L. Burton, A. L. Kuck, and S. Schnell. 2005. Genetic basis and risk factors for infectious and noninfectious diseases in US Holsteins. I. Estimation of genetic parameters for single diseases and general health. J. Dairy Sci. 88:1199-1207. https://doi.org/10.3168/jds. S0022-0302(05)72786-7.

Ahmadi, K. R., M. A. Hall, P. Norman, R. W. Vaughan, H. Snieder, T. D. Spector, and J. S. Lanchbury. 2001. Genetic determinism in the relationship between human CD4+ and CD8+ T lymphocyte populations? Genes Immun. 2:381-387. https://doi.org/10.1038/ sj.gene.6363796.

Amadori, A., R. Zamarchi, G. De Silvestro, G. Forza, G. Cavatton, G. A. Danieli, M. Clementi, and L. Chieco-Bianchi. 1995. Genetic control of the CD4/CD8 T-cell ratio in humans. Nat. Med. 1:1279 1283. https://doi.org/10.1038/nm1295-1279.

Banos, G., E. Wall, M. P. Coffey, A. Bagnall, S. Gillespie, G. C. Russell, and T. N. McNeilly. 2013. Identification of immune traits correlated with dairy cow health, reproduction and productivity. PLoS One 8:e65766. https://doi.org/10.1371/journal.pone.0065766.

Bartik, M. M., D. Welker, and N. E. Kay. 1998. Impairments in immune cell function in B cell chronic lymphocytic leukemia. Semin. Oncol. 25:27-33.

Bell, M. J., E. Wall, G. Russell, G. Simm, and A. W. Stott. 2011. The effect of improving cow productivity, fertility, and longevity on the global warming potential of dairy systems. J. Dairy Sci. 94:3662-3678. https://doi.org/10.3168/jds.2010-4023.

Berrih, S., C. Gaud, M. A. Bach, H. Le Brigand, J. P. Binet, and J. F. Bach. 1981. Evaluation of $\mathrm{T}$ cell subsets in myasthenia gravis using anti-T cell monoclonal antibodies. Clin. Exp. Immunol. 45:1-8.

Bevan, M. J. 2004. Helping the CD8(+) T-cell response. Nat. Rev. Immunol. 4:595-602. https://doi.org/10.1038/nri1413.

Clapperton, M., S. C. Bishop, and E. J. Glass. 2005. Innate immune traits differ between Meishan and Large White pigs. Vet. Immunol. Immunopathol. 104:131-144. https://doi.org/10.1016/j. vetimm.2004.10.009.

Clapperton, M., A. B. Diack, O. Matika, E. J. Glass, C. D. Gladney, M. A. Mellencamp, A. Hoste, and S. C. Bishop. 2009. Traits associated with innate and adaptive immunity in pigs: heritability and associations with performance under different health status conditions. Genet. Sel. Evol. 41:54. https://doi.org/10.1186/12979686-41-54.

Clapperton, M., E. J. Glass, and S. C. Bishop. 2008. Pig peripheral blood mononuclear leucocyte subsets are heritable and genetically correlated with performance. Animal 2:1575-1584. https://doi. org/10.1017/S1751731108002929. 
Clementi, M., P. Forabosco, A. Amadori, R. Zamarchi, G. De Silvestro, E. Di Gianantonio, L. Chieco-Bianchi, and R. Tenconi. 1999. CD4 and CD8 T lymphocyte inheritance. Evidence for major autosomal recessive genes. Hum. Genet. 105:337-342.

Collard, B. L., P. J. Boettcher, J. C. Dekkers, D. Petitclerc, and L. R. Schaeffer. 2000. Relationships between energy balance and health traits of dairy cattle in early lactation. J. Dairy Sci. 83:2683-2690. https://doi.org/10.3168/jds.S0022-0302(00)75162-9.

de Klerk, B., B. J. Ducro, H. C. M. Heuven, I. den Uyl, J. M. van Arendonk, H. K. Parmentier, and J. J. van der Poel. 2015. Phenotypic and genetic relationships of bovine natural antibodies binding keyhole limpet hemocyanin in plasma and milk. J. Dairy Sci. 98:2746-2752. https://doi.org/10.3168/jds.2014-8818.

Denis, M., S. J. Lacy-Hulbert, B. M. Buddle, J. H. Williamson, and D. N. Wedlock. 2011. Streptococcus uberis-specific T cells are present in mammary gland secretions of cows and can be activated to kill S. uberis. Vet. Res. Commun. 35:145-156. https://doi. org/10.1007/s11259-011-9462-1.

Ewald, S. J., Y. Y. Lien, L. Li, and L. W. Johnson. 1996. B-haplotype control of CD4/CD8 subsets and TCR V beta usage in chicken T lymphocytes. Vet. Immunol. Immunopathol. 53:285-301. https:// doi.org/10.1016/S0165-2427(96)05613-9.

Fahey, J. L., J. M. Taylor, R. Detels, B. Hofmann, R. Melmed, P. Nishanian, and J. V. Giorgi. 1990. The prognostic value of cellular and serologic markers in infection with human immunodeficiency virus type 1. N. Engl. J. Med. 322:166-172. https://doi. org/10.1056/NEJM199001183220305.

Flori, L., Y. Gao, D. Laloë, G. Lemonnier, J.-J. Leplat, A. Teillaud, A.-M. Cossalter, J. Laffitte, P. Pinton, C. de Vaureix, M. Bouffaud, M.-J. Mercat, F. Lefèvre, I. P. Oswald, J.-P. Bidanel, and C. Rogel-Gaillard. 2011a. Immunity traits in pigs: Substantial genetic variation and limited covariation. PLoS One 6:e22717 https://doi. org/10.1371/journal.pone.0022717.

Flori, L., Y. Gao, I. P. Oswald, F. Lefevre, M. Bouffaud, M.-J. Mercat, J.-P. Bidanel, and C. Rogel-Gaillard. 2011b. Deciphering the genetic control of innate and adaptive immune responses in pig: A combined genetic and genomic study. BMC Proc. 5:S32. https:// doi.org/10.1186/1753-6561-5-S4-S32.

Gilmour, A., B. Gogel, B. Cullis, and R. Thompson. 2009. ASReml user guide release 3.0. VSN International Ltd., Hemel Hempstead, UK.

Glass, E. J., P. M. Preston, A. Springbett, S. Craigmile, E. Kirvar, G. Wilkie, and C. G. D. Brown. 2005. Bos taurus and Bos indicus (Sahiwal) calves respond differently to infection with Theileria annulata and produce markedly different levels of acute phase proteins. Int. J. Parasitol. 35:337-347. https://doi.org/10.1016/j. ijpara.2004.12.006.

Gonzalez-Rodriguez, A. P., J. Contesti, L. Huergo-Zapico, A. LopezSoto, A. Fernández-Guizán, A. Acebes-Huerta, A. J. GonzalezHuerta, E. Gonzalez, C. Fernandez-Alvarez, and S. Gonzalez. 2010. Prognostic significance of CD8 and CD4 T cells in chronic lymphocytic leukemia. Leuk. Lymphoma 51:1829-1836. https:// doi.org/10.3109/10428194.2010.503820.

Gorczyca, W., J. Weisberger, Z. Liu, P. Tsang, M. Hossein, C. D. Wu, H. Dong, J. Y. L. Wong, S. Tugulea, S. Dee, M. R. Melamed, and Z. Darzynkiewicz. 2002. An approach to diagnosis of t-cell lymphoproliferative disorders by flow cytometry. Cytometery 50:177-190. /https://doi.org/10.1002/cyto.10003.

Gupta, S. 1980. Subpopulations of human T lymphocytes. XVI. Maldistribution of $\mathrm{T}$ cell subsets associated with abnormal locomotion of T cells in untreated adult patients with Hodgkin's disease. Clin. Exp. Immunol. 42:186-195.

Hadrup, S. R., J. Strindhall, T. Køllgaard, T. Seremet, B. Johansson, G. Pawelec, P. thor Straten, and A. Wikby. 2006. Longitudinal studies of clonally expanded CD8 T cells reveal a repertoire shrinkage predicting mortality and an increased number of dysfunctional cytomegalovirus-specific $\mathrm{T}$ cells in the very elderly. J. Immunol. $176: 2645-2653$.

Hall, M. A., K. R. Ahmadi, P. Norman, H. Snieder, A. J. MacGregor, R. W. Vaughan, T. D. Spector, and J. S. Lanchbury. 2000. Genetic influence on peripheral blood T lymphocyte levels. Genes Immun. 1:423-427. https://doi.org/10.1038/sj.gene.6363702.

Heriazon, A., M. Quinton, F. Miglior, K. E. Leslie, W. Sears, and B. A. Mallard. 2013. Phenotypic and genetic parameters of antibody and delayed-type hypersensitivity responses of lactating Holstein cows. Vet. Immunol. Immunopathol. 154:83-92. https://doi. org/10.1016/j.vetimm.2013.03.014.

Hernandez, O., T. Oweity, and S. Ibrahim. 2005. Is an increase in $\mathrm{CD} 4 / \mathrm{CD} 8 \mathrm{~T}$-cell ratio in lymph node fine needle aspiration helpful for diagnosing Hodgkin lymphoma? A study of 85 lymph node FNAs with increased CD4/CD8 ratio. Cytojournal 2:14. https:// doi.org/10.1186/1742-6413-2-14.

Hiss, S., C. Weinkauf, S. Hachenberg, and H. Sauerwein. 2009. Short communication: Relationship between metabolic status and the milk concentrations of haptoglobin and lactoferrin in dairy cows during early lactation. J. Dairy Sci. 92:4439-4443. https://doi. org/10.3168/jds.2008-1632.

Huijps, K., T. J. Lam, and H. Hogeveen. 2008. Costs of mastitis: Facts and perception. J. Dairy Res. 75:113-120. https://doi. org/10.1017/S0022029907002932.

Karcheva, M., T. Lukanov, S. Gecheva, V. Slavcheva, G. Veleva, and R. Nachev. 2008. Infectious mononucleosis-Diagnostic potentials. Pages 9-13 in Journal of IMAB-Annual Proceeding (scientific papers) Book 1. Peytchinski Gospodin Iliev, Pleven, Bulgaria.

King, K., S. Smith, M. Chapman, and G. Sacks. 2010. Detailed analysis of peripheral blood natural killer (NK) cells in women with recurrent miscarriage. Hum. Reprod. 25:52-58. https://doi. org/10.1093/humrep/dep349.

Koeck, A., F. Miglior, J. Jamrozik, D. F. Kelton, and F. S. Schenkel. 2013. Genetic associations of ketosis and displaced abomasum with milk production traits in early first lactation of Canadian Holsteins. J. Dairy Sci. 96:4688-4696. https://doi.org/10.3168/ jds.2012-6408.

Kraal, G., I. L. Weissman, and E. C. Butcher. 1983. Genetic control of T-cell subset representation in inbred mice. Immunogenetics 18:585-592.

Kwak-Kim, J., and A. Gilman-Sachs. 2008. Clinical implication of natural killer cells and reproduction. Am. J. Reprod. Immunol. 59:388-400. https://doi.org/10.1111/j.1600-0897.2008.00596.x.

Lu, W., V. Mehraj, K. Vyboh, W. Cao, T. Li, and J. P. Routy. 2015. CD4:CD8 ratio as a frontier marker for clinical outcome, immune dysfunction and viral reservoir size in virologically suppressed HIV-positive patients. J. Int. AIDS Soc. 18:20052. https://doi. org/10.7448/IAS.18.1.20052.

Lun, S., G. Aström, U. Magnusson, and K. Ostensson. 2007. Total and differential leucocyte counts and lymphocyte subpopulations in lymph, afferent and efferent to the supramammary lymph node, during endotoxin-induced bovine mastitis. Reprod. Domest. Anim. 42:126-134. https://doi.org/10.1111/j.1439-0531.2006.00741.x.

Mallard, B. A., H. Atalla, S. Cartwright, B. C. Hine, B. Hussey, M. Paibomesai, K. A. Thompson-Crispi, and L. Wagter-Lesperance. 2011. Genetic and epigenetic regulation of the bovine immune system: Practical implications of the high immune response technology. Pages 53-61 in Proc. National Mastitis Council 50th Annual Meeting. National Mastitis Council, Madison, WI.

Mallard, B. A., M. Emam, M. Paibomesai, K. A. Thompson-Crispi, and L. Wagter-Lesperance. 2015. Genetic selection of cattle for improved immunity and health. Jpn. J. Vet. Res. 63:S37-S44. https://doi.org/10.14943/jjvr.63.suppl.s37.

March, M. D., L. Toma, W. Stott, and D. J. Roberts. 2016. Modelling phosphorus efficiency within diverse dairy farming systemsPollutant and non-renewable resource? Ecol. Indic. 69:667-676. https://doi.org/10.1016/j.ecolind.2016.05.022.

Matsui, M., and M. Kameyama. 1986. A double-label flow cytometric analysis of the simultaneous expression of OKT4 and Leu2a antigens on circulating $\mathrm{T}$ lymphocytes in myasthenia gravis. J. Neuroimmunol. 11:311-319. https://doi.org/10.1016/01655728(86)90084-6.

McDougall, S., D. G. Arthur, M. A. Bryan, J. J. Vermunt, and A. M. Weir. 2007. Clinical and bacteriological response to treatment of 
clinical mastitis with one of three intramammary antibiotics. N. Z. Vet. J. 55:161-170. https://doi.org/10.1080/00480169.2007.36762.

Michou, V. I., P. Kanavaros, V. Athanassiou, G. B. Chronis, S. Stabamas, and V. Tsilivakos. 2003. Fraction of the peripheral blood concentration of CD56+/CD16-/CD3- cells in total natural killer cells as an indication of fertility and infertility. Fertil. Steril. 80:691-697. https://doi.org/10.1016/S0015-0282(03)00778-7.

Miglior, F., B. L. Muir, and B. J. Van Doormaal. 2005. Selection indices in Holstein cattle of various countries. J. Dairy Sci. 88:12551263. https://doi.org/10.3168/jds.S0022-0302(05)72792-2.

Mrode, R. A., and G. J. T. Swanson. 1996. Genetic and statistical properties of somatic cell count and its suitability as an indirect means of reducing the incidence of mastitis in dairy cattle. Anim. Breed. Abstr. 64:847-856.

Mrode, R. A., and G. J. T. Swanson. 2003. Estimation of genetic parameters for somatic cell count in the first three lactations using random regression. Livest. Prod. Sci. 79:239-247. https://doi. org/10.1016/S0301-6226(02)00169-0.

Myrick, C., R. DiGuisto, J. DeWolfe, E. Bowen, J. Kappler, P. Marrack, and E. K. Wakeland. 2002. Linkage analysis of variations in CD4:CD8 T cell subsets between C57BL/6 and DBA/2. Genes Immun. 3:144-150. https://doi.org/10.1038/sj.gene.6363819.

Nakayamada, S., H. Takahashi, Y. Kanno, and J. J. O'Shea. 2012 Helper $\mathrm{T}$ cell diversity and plasticity. Curr. Opin. Immunol. 24:297-302. https://doi.org/10.1016/j.coi.2012.01.014.

Oltenacu, P. A., and D. M. Broom. 2010. The impact of genetic selection for increased milk yield on the welfare of dairy cows. Anim. Welf. 19:39-49.

Park, Y. H., Y. S. Joo, J. Y. Park, J. S. Moon, S. H. Kim, N. H. Kwon, J. S. Ahn, W. C. Davis, and C. J. Davies. 2004. Characterization of lymphocyte subpopulations and major histocompatibility complex haplotypes of mastitis-resistant and susceptible cows. J. Vet. Sci. 5:29-39.

Pender, M. P., P. A. Csurhes, C. M. Pfluger, and S. R. Burrows. 2014. Deficiency of CD8+ effector memory T cells is an early and persistent feature of multiple sclerosis. Mult. Scler. 20:1825-1832. https://doi.org/10.1177/1352458514536252.

Poppema, S. 1996. Immunology of Hodgkin's disease. Baillieres Clin. Haematol. 9:447-457. https://doi.org/10.1016/S09503536(96)80020-5.

Pritchard, T., M. P. Coffey, R. Mrode, and E. Wall. 2013. Genetic parameters for production, health, fertility and longevity traits in dairy cows. Animal 7:34-46. https://doi.org/10.1017/ S1751731112001401.

Pryce, J. E., B. L. Nielsen, R. F. Veerkamp, and G. Simm. 1999 Genotype and feeding system effects and interactions for health and fertility traits in dairy cattle. Livest. Prod. Sci. 57:193-201. https://doi.org/10.1016/S0301-6226(98)00180-8.

Pryce, J. E., M. D. Royal, P. C. Garnsworthy, and I. L. Mao. 2004. Fertility in the high-producing dairy cow. Livest. Prod. Sci. 86:125-135. https://doi.org/10.1016/S0301-6226(03)00145-3.

Saama, P. M., J. B. Jacob, M. E. Kehrli, A. E. Freeman, S. C. Kelm, A. L. Kuck, R. J. Tempelman, and J. L. Burton. 2004. Genetic variation in bovine mononuclear leukocyte responses to dexamethasone. J. Dairy Sci. 87:3928-3937. https://doi.org/10.3168/jds. S0022-0302(04)73532-8.

Salih, S. M. 2009. Lymphocyte subsets phenotype in patients with infectious mononucleosis. J. Fac. Med. Baghdad 51:227-231.

Serrano-Villar, S., T. Sainz, and S. Moreno. 2015. Monitoring the $\mathrm{CD} 4 / \mathrm{CD} 8$ ratio: a promising indicator of disease progression in HIV-infected individuals? Future Virol. 10:1-4. https://doi. org $/ 10.2217 /$ fvl.14.85.

Seshadri, S., and S. K. Sunkara. 2014. Natural killer cells in female infertility and recurrent miscarriage: A systematic review and meta-analysis. Hum. Reprod. Update 20:429-438. https://doi. org/10.1093/humupd/dmt056.

Sivori, S., M. Vitale, L. Morelli, L. Sanseverino, R. Augugliaro, C. Bottino, L. Moretta, and A. Moretta. 1997. P46, a novel natural killer cell-specific surface molecule that mediates cell activation. J. Exp. Med. 186:1129-1136. https://doi.org/10.1084/jem.186.7.1129.

Stoop, C. L., K. A. Thompson-Crispi, S. Cartwright, and B. A. Mallard. 2016. Short communication: Variation in production parameters among Canadian Holstein cows classified as high, average, and low immune responders. J. Dairy Sci. 99:4870-4874. https:// doi.org/10.3168/jds.2015-10145.

Storset, A. K., S. Kulberg, I. Berg, P. Boysen, J. C. Hope, and E. Dissen. 2004. NKp46 defines a subset of bovine leukocytes with natural killer cell characteristics. Eur. J. Immunol. 34:669-676. https://doi.org/10.1002/eji.200324504.

Strindhall, J., B. O. Nilsson, S. Löfgren, J. Ernerudh, G. Pawelec, B. Johansson, and A. Wikby. 2007. No Immune Risk Profile among individuals who reach 100 years of age: Findings from the Swedish NONA immune longitudinal study. Exp. Gerontol. 42:753-761. https://doi.org/10.1016/j.exger.2007.05.001.

Tassi, R., T. N. McNeilly, J. L. Fitzpatrick, M. C. Fontaine, D. Reddick, C. Ramage, M. Lutton, Y. H. Schukken, and R. N. Zadoks. 2013. Strain-specific pathogenicity of putative host-adapted and nonadapted strains of Streptococcus uberis in dairy cattle. J. Dairy Sci. 96:5129-5145. https://doi.org/10.3168/jds.2013-6741.

Taylor, B. C., R. G. Keefe, J. D. Dellinger, Y. Nakamura, J. S. Cullor, and J. L. Stott. 1997. T cell populations and cytokine expression in milk derived from normal and bacteria-infected bovine mammary glands. Cell. Immunol. 182:68-76. https://doi.org/10.1006/ cimm.1997.1215.

Thompson-Crispi, K. A., H. Atalla, F. Miglior, and B. A. Mallard. 2014a. Bovine mastitis: Frontiers in immunogenetics. Front. Immunol. 5:493. https://doi.org/10.3389/fimmu.2014.00493.

Thompson-Crispi, K. A., B. Hine, M. Quinton, F. Miglior, and B. A. Mallard. 2012a. Short communication: Association of disease incidence and adaptive immune response in Holstein dairy cows. J. Dairy Sci. 95:3888-3893. https://doi.org/10.3168/jds.2011-5201.

Thompson-Crispi, K. A., F. Miglior, and B. A. Mallard. 2013. Incidence rates of clinical mastitis among Canadian Holsteins classified as high, average, or low immune responders. Clin. Vaccine Immunol. 20:106-112. https://doi.org/10.1128/CVI.00494-12.

Thompson-Crispi, K. A., M. Sargolzaei, R. Ventura, M. Abo-Ismail, F. Miglior, F. Schenkel, and B. A. Mallard. 2014b. A genome-wide association study of immune response traits in Canadian Holstein cattle. BMC Genomics 15:559 https://doi.org/10.1186/1471-2164$15-559$.

Thompson-Crispi, K. A., A. Sewalem, F. Miglior, and B. A. Mallard. 2012b. Genetic parameters of adaptive immune response traits in Canadian Holsteins. J. Dairy Sci. 95:401-409. https:// doi.org/10.3168/jds.2011-4452.

van Knegsel, A. T. M., M. Hostens, G. de Vries Reilingh, A. Lammers, B. Kemp, G. Opsomer, and H. K. Parmentier. 2012. Natural antibodies related to metabolic and mammary health in dairy cows. Prev. Vet. Med. 103:287-297. https://doi.org/10.1016/j. prevetmed.2011.09.006.

Veerkamp, R. F., G. Simm, and J. D. Oldham. 1994. Effects of interaction between genotype and feeding system on milk production, feed intake, efficiency and body tissue mobilization in dairy cows. Livest. Prod. Sci. 39:229-241. https://doi.org/10.1016/03016226(94)90202-X

Wikby, A., P. Maxson, J. Olsson, B. Johansson, and F. G. Ferguson. 1998. Changes in CD8 and CD4 lymphocyte subsets, T cell proliferation responses and non-survival in the very old: The Swedish longitudinal OCTO-immune study. Mech. Ageing Dev. 102:187198. https://doi.org/10.1016/S0047-6374(97)00151-6.

Zhang, Q., Q. Li, J.-W. Xu, A.-M. Zhang, X.-C. Xu, and Z.-M. Zhai. 2007. Clinical significance of detection of T-cell subgroups in patients with aplastic anemia. Zhongguo Shi Yan Xue Ye Xue Za Zhi 15:1046-1049.

Zhu, J., and W. E. Paul. 2008. CD4 T cells: Fates, functions, and faults. Blood 112:1557-1569. https://doi.org/10.1182/ blood-2008-05-078154. 